\title{
Wendy De Bondt* \\ Cooperation in Criminal Matters Through the Eyes of the Luxembourg Court: The Case Law of 2019
}

\section{Abstract}

In the course of 2019 , the Luxembourg court was invited to reflect and rule on the interpretation of different provisions within the EU's legal framework governing cooperation in criminal matters. Analysis of the court's case law reveals that eight themes can be distinguished across eight cooperation instruments: (1) the law governing the execution of a confiscation order; (2) the impact of preliminary rulings on the deadlines set for release of persons arrested in execution of a European arrest warrant; (3) the position of public prosecutors in issuing a European arrest warrant; (4) the scope and effect of the Directive on Victim Rights to national criminal procedural law; (5) the impact of a mental illness on the applicability of the Directive on the right to information and the Directive on the access to a lawyer; (6) the use of problematic detention conditions as a ground to refuse cooperation; (7) the need to have a legal remedy against the issuing of a European investigation order; and (8) the scope of the Directive on the presumption of innocence and the EU Charter of Fundamental Rights.

Keywords: CJEU, confiscation order, preliminary ruling, victim rights, mental illness, presumption of innocence, competent authority

Clustered in eight themes, this contribution provides an overview of the cases the Court of Justice of the European Union (hereafter, the 'CJEU') ruled on in 2019 and the court's argumentation therein, against the background of existing case law and the views shared in academic literature. ${ }^{1}$ In doing so, the article provides an overview of the position of the CJEU regarding the interpretation of either the scope of, or specific provisions in the following EU legal instruments: the European arrest warrant, the confiscation order, the victim directive, the European investigation order, the directive on the right to information, the directive on access to a lawyer, the directive regarding the presumption of innocence and the EU Charter of fundamental rights. These instru-

* Wendy De Bondt is a professor of criminal law, juvenile delinquency and children's rights law at Ghent University (Belgium) and member of IRCP and HRC (Human Rights Centre).

1 See for my preliminary thoughts on this W. De Bondt, De interpretatie van het juridisch kader rond justitiële samenwerking in strafzaken: een overzicht van de Luxemburgse rechtspraak uit 2019, Panopticon 2020, 41(1), p.92 - 98. 
ments feature in one or more of the eight thematic clusters used to structure this contribution.

1. Recourse to imprisonment in the context of executing a confiscation order

The CJEU started its year with a judgment regarding the cross-border execution of confiscation orders. The question put to the court related to the acceptability of seeking recourse to imprisonment in case of non-execution of the confiscation order and whether this could be decided on without the explicit prior consent of the original decision state. More fundamentally, the question related to the law applicable to the execution of a confiscation order and the extent to which applying that law needs to take account of the law of the issuing member state. From a conceptual perspective, this question can be brought back to discussions on the scope of 'locus regit actum', 'forum regit actum' and 'best of both worlds' concepts as guiding principles in the future ideal landscape of cooperation in criminal matters. ${ }^{2}$

The facts underlying case C- $97 / 18^{3}$ may be summarised as follows. E.T. was sentenced by the Court of Appeal in Antwerp (Belgium) to a confiscation of 800.000 euro. With a view to the execution of that sentence, a confiscation order was drawn up based on Framework Decision 2006/7834 and addressed to The Netherlands. It is in that context that the Dutch public prosecutor lodged an application before the referring court, seeking leave to enforce a term of imprisonment against E.T., on the ground that part of the sum was outstanding and that the prosecution suspected there to be invisible financial flows.

A three-fold question arose, namely (1) whether recourse to imprisonment would require the prior consent of the issuing state, (2) whether this would constitute a prohibited aggravation of the confiscation order of which enforcement is sought, rendering the imprisonment unlawful and (3) whether recourse to imprisonment should be dependent on the reciprocal existence of an imprisonment possibility in the issuing state.

The court's reply was negative in relation to all three points. The imprisonment stemming from the non-execution of the confiscation should be qualified as a way of executing the confiscation order. Pursuant to Article 12 Framework Decision $2006 / 783$, execution of confiscation orders is governed by the law of the executing state. In this case, it is clear that locus regit actum applies, with the executing state being the locus state. Furthermore, the imprisonment would never qualify as 'an alternative' to the confiscation, so that the requirement of receiving prior consent of the issuing state could never come into play. In doing so, the CJEU takes the opportunity pre-

2 G. Vermeulen, W. De Bondt and C. Ryckman, Rethinking international cooperation in criminal matters in the EU: moving beyond actors, bringing logic back, footed in reality, Maklu, 2012.

3 Court of Justice of the European Union (CJEU), 10.01.2019, case C-97/18 (E.T.).

4 Council Framework Decision 2006/783/JHA of 6 October 2006 on the application of the principle of mutual recognition to confiscation orders, OJ 2006 L 328. 
sented in this case to confirm the exclusive primacy of the law of the executing state in deciding on the enforcement procedures. This entails that it is up to the executing state to independently determine the applicable rules based on its domestic legislation and that the nature of the measures and procedures in the issuing state is completely irrelevant. ${ }^{5}$ This reasoning is perfectly in line with the mutual recognition principle underlying cooperation, which implies that issuing Member States accept the application of the criminal law in force in the executing Member States, even though the application of its own national law might lead to a different outcome. It consistently reiterates the court's position detailed in previous case law. ${ }^{6}$

2. The lack of suspension of time limits awaiting the outcome of a reference for a preliminary ruling

During the next month, the court looked into the impact of a reference for a preliminary ruling on the time limits set forth in the legal framework governing the execution of European arrest warrants. Though the case related to the European arrest warrant, it is our conviction that the reasoning may also be applied to the time limits found in other instruments, such as for example the European investigation order. ${ }^{7}$

In case C-492/18 a British citizen T.C. had been deprived of his liberty following the execution of a European arrest warrant. ${ }^{8}$ Suspected of being involved in the importation, supply and sale of hard drugs, including $300 \mathrm{~kg}$ of cocaine, the UK government had issued a European arrest warrant which led to the arrest of T.C. in The Netherlands. Before the time limits stipulated in Article 17 Framework Decision 2002/5849 had expired, the case was referred to the CJEU for a preliminary ruling. In the context thereof, the question arose whether the time limits included in the Framework Decision would be suspended awaiting the outcome of that procedure. The importance thereof cannot be overestimated given the impact on the length of pre-trial detention, which is often voiced as a concern. ${ }^{10}$

5 See also T. Piay, La STJUE de 10 de enero de 2019 (Asunto C-97/18): cooperación judicial, decomiso y arresto por impago, Revista General de Derecho Procesal, 2019, 49.

6 Court of Justice of the European Union (CJEU), 16.02.2017, case C- 507/15 (Agro Foreign Trade \& Agency); Court of Justice of the European Union (CJEU), 23.01.2018, case C367/16 (Piotrowski).

7 Directive 2014/41/EU of the European Parliament and of the Council of 3 April 2014 regarding the European Investigation Order in criminal matters, OJ $2014 \mathrm{~L} 130$.

8 Court of Justice of the European Union (CJEU), 12.02.2019, case C 492/18 PPU (T.C.).

9 Council Framework Decision of 13 June 2002 on the European arrest warrant and the surrender procedures between Member States, OJ 2002 L 190.

10 A. Van Kalmthout, M. Knapen and C. Morgenstern, Pre-trial Detention in the European Union, An Analysis of Minimum Standards in Pre-trial Detention and the Grounds for Regular Review in the Member States of the EU, Wolf Legal Publishers 2009; C. Rieble and A. Clozel 10 years after the roadmap: procedural rights in criminal proceedings in the EU today, ERA Forum 2020 (20), 321-325. 
The CJEU firmly stressed that such a suspension would not be acceptable under any condition. In its judgment of 12 February 2019, the Court strongly argued against it, referring to the general and unconditional obligation to release the requested person provisionally after expiry of the time limits stipulated in Article 17 Framework Decision 2002/584. Any other interpretation thereof could limit the effectiveness of the surrender system put in place by that framework decision and, consequently, obstruct attaining its objectives. ${ }^{11}$ To further substantiate its reasoning, the court refers to Article 6 of the EU Charter of Fundamental Rights which must be interpreted as precluding national (case-)law which allows the requested person to be kept in detention beyond that 90 -day period. National provisions allowing for a suspension of the time limits when the executing judicial authority decides to refer a question to the CJEU for a preliminary ruling, or to await the reply to a request for a preliminary ruling made by another executing judicial authority are not in conformity with EU law. The same applies to national provisions who postpone the decision on surrender on the ground that there could be, in the issuing Member State, a real risk of inhuman or degrading detention conditions.

\section{The qualification of the public prosecutor as a competent judicial authority}

A recurring topic, also in last year's case law, relates to the position of the public prosecutor in instruments governing cooperation in criminal matters, and more specifically whether or not a public prosecutor can be accepted as a competent judicial authority issuing cooperation orders. In light thereof a significant number of judgments in 2019 contributed to the refinement of the interpretation of 'competent judicial authority'. Interestingly, all 2019 cases on the interpretation of this concept related to the position of the public prosecutor, whereas in previous years, also the positions of police authorities $^{12}$ or Ministries of Justice ${ }^{13}$ had been under scrutiny. Building on its previous case law, the court echoed and elaborated existing lines of reasoning.

The court reiterates that when it regards a measure such as the issuing of a European arrest warrant, which is capable of impinging on the right to liberty of the person concerned - as enshrined in Article 6 of the EU Charter of Fundamental Rights - that protection means that a decision meeting the requirements inherent in effective judicial protection should be adopted. It follows from the principle of national procedural autonomy that the issuing Member State may confer the competence to issue a European

11 See also Court of Justice of the European Union (CJEU), 16.07.2015, case C 237/15 PPU (Lanigan).

12 See e.g. the case where the Dutch court questioned the validity of an EAW issued by the Swedish police. Court of Justice of the European Union (CJEU), 10.11.2016, case C-452/16 (Poltorak).

13 See e.g. the case where the Dutch court questioned the validity of an EAW issued by the Lithuanian Ministry of Justice. Court of Justice of the European Union (CJEU), 10.11.2016, case C-477/16 (Kovalkovas). 
arrest warrant on an authority which, whilst participating in the administration of justice in that Member State, is not a judge or a court.

A first string of judgments regarding the position of the public prosecutor's office was issued on 27 May 2019. In case C-82/19 PPU, the German public prosecutor had issued a European arrest warrant against a Romanian citizen (P.I.), with a view to his prosecution for facts related to organised or armed robbery. Similarly, in case C-508/18 14 , the German public prosecutor's office was under scrutiny for having issued a European arrest warrant for the arrest of O.G., a Lithuanian citizen residing in Ireland, suspected of murder and grievous bodily injury. Both suspects had challenged the validity of the EAWs and in both cases their reasoning was followed by the CJEU. According to the CJEU, the concept of 'competent judicial authority' must be interpreted as not including public prosecutors' offices of a Member State which are exposed to the risk of being subject, directly or indirectly, to directions or instructions in a specific case from the executive, such as a Minister for Justice, in connection with the adoption of a decision to issue a European arrest warrant. ${ }^{15}$

Case C-509/18 shows important similarities to the previous two and one might anticipate a similar outcome. ${ }^{16}$ Here too a European arrest warrant was issued by the public prosecutor. The case relates to a warrant issued by the Lithuanian ProsecutorGeneral, for the arrest of P.F., suspected of having committed an armed robbery. The difference with the previous two cases however stems from the difference in the national organisation of the prosecution and the strictness of the separation of powers. ${ }^{17}$ Within the Lithuanian state structure, the Prosecutor-General of Lithuania is the most senior public prosecutor. He has the status of a public prosecutor and is independent both of the executive and the judiciary. In respect of public prosecutors, Article 118 of the Lithuanian constitution provides that their function is to organise and direct pretrial criminal investigations and to conduct criminal prosecutions. However, according to the case-law of the Lithuanian Constitutional Court, a public prosecutor is not responsible for the administration of justice and he also does not perform any functions related to the administration of justice during any pre-trial criminal investigation for which he is responsible. Having analysed the Lithuanian legal system, the CJEU con-

14 Court of Justice of the European Union (CJEU), 27.05.2019, joint cases C-508/18 (O.G.) and C-82/19 PPU (P.I.).

15 See for a more elaborate analysis of these joint cases C. Heimrich, European arrest warrants and the independence of the issuing judicial authority - How much independence is required? (Case note on joined cases C-508/18 and C-82/19 PPU OG and PI), New Journal of European Criminal Law, 2019, Vol. 10(4) 389-398; K. Ambos, The German Public Prosecutor as (no) judicial authority within the meaning of the European Arrest Warrant: A case note on the CJEU's judgment in OG (C-508/18) and PI (C 82/19 PPU), New Journal of European Criminal law, 2019, Vol. 10(4) 399-407; V. Mitsilegas, Autonomous concepts, diversity management and mutual trust in Europe's area of criminal justice, Common Market Law Review, 2020, 57(1), 45-78.

16 Court of Justice of the European Union (CJEU), 27.05.2019, case C-509/18(P.F.).

17 Prosecutorial independence has been subject to wide academic debate. See e.g. J. Gutmann and S. Voigt, Judicial independence in the EU: a puzzle, European Journal of Law and Economics, 2020 (49), 83-100.

EuCLR Vol. 10, 2/2020 
cluded that the EU concept of 'competent judicial authority' must be interpreted as including the Prosecutor-General of a Member State who, whilst institutionally independent from the judiciary, is responsible for the conduct of criminal prosecutions and whose legal position, in that Member State, affords him a guarantee of independence from the executive in connection with the issuing of a European arrest warrant. ${ }^{18}$

A second string of judgments related to the a priori or a posteriori intervention of a judicial authority. In case C-489/19, a European arrest warrant was issued by an Austrian public prosecutor, receiving an a posteriori validation by the landesgericht. ${ }^{19}$ Completely in line with its previous case law, the CJEU decided on 9 October 2019 that - despite the fact that a public prosecutor's office is exposed to the risk of being subject, directly or indirectly, to directions or instructions in a specific case from the executive, such as a Minister for Justice - the European arrest warrant is still valid, provided that it is subject to endorsement by a court which reviews independently and objectively the conditions of issue and the proportionality of those arrest warrants having access to the entire criminal file to which any specific directions or instructions from the executive are added. In doing so, it is ensured that a court adopts an autonomous decision, giving the European arrest warrant its final form. It is clear from this case law that the European arrest warrant obtains its validity through the a posteriori validation procedure. In addition thereto, national legal systems can also install a mechanism or practice that relies on a priori validation. In the case C-626/19 PPU, the judicial control had taken place in an a priori fashion. The European arrest warrant issued by the public prosecutor of Tours against Y.C. suspected of being involved in an armed robbery, constituted 'the follow up' of a national arrest warrant issued earlier that day, by a Tours judge. Similarly, in case C-566/19, the European arrest warrant issued by the public prosecutor of Lyon against J.R., suspected of being part of a criminal organisation, stemmed from a national arrest warrant delivered by a Lyon judge earlier the same day. ${ }^{20}$ In analogy to these two cases, a third case may be added. In case C-625/19, a European arrest warrant was issued by a Swedish public prosecutor upon a court decision for the pre-trial detention of X.D. suspected of several counts of drugrelated offences committed in the context of a criminal organisation..$^{21}$ In the judgments of 12 December 2019, the CJEU maintained that there is no problem in accepting the validity of European arrest warrants issued by either the French or Swedish public prosecutors, given that they were acting in furtherance or execution of pre-existing judicial decisions relating to either national arrest warrants or decisions to commit a person to pre-trial detention.

18 This case is briefly commented on in M. Plachta, EU Court of Justice Clarifies the Concept of "Judicial Issuing

Authority" in the European Arrest Warrant's Procedure, International Enforcement Law Reporter 2019, 35(6), 210-212.

19 Court of Justice of the European Union (CJEU), 09.10.2019, case C-489/19 (N.J.).

20 Court of Justice of the European Union (CJEU), 12.12.2019, joint cases C-626/19 PPU (YC.) and C-566/19 (J.R.).

21 Court of Justice of the European Union (CJEU), 12.12.2019, case C-625/19 (X.D.). 
On 12 December 2019, the CJEU issued a final arrest on this theme. In case C-627/19 PPU, a European arrest warrant issued by the Brussels public prosecutor with a view to seeking the execution of a sentence involving the deprivation of liberty, was under scrutiny. ${ }^{22}$ The specific 'sentence execution'-context in which the European arrest warrant was issued, merits a separate reflection in this overview. The CJEU clearly argued that given the pre-existence of an executable court sentence, following a procedure encompassing all necessary procedural safeguards as required in amongst others Article 47 of EU Charter of Fundamental Rights and which effectively refutes the presumption of innocence of the person involved, there is no need for an additional judicial or court involvement in the issuing of a European arrest warrant. The EU concept of 'competent judicial authority' must therefore be interpreted as not excluding an authority which participates to rendering justice without being a judicial authority and without providing a separate procedure to challenge the European arrest warrant. The opportunity to challenge is deemed sufficiently included in the judicial procedure leading up to the conviction.

4. Balancing the rights of the defence and the rights of the victims in criminal procedures

In case C-38/18, the court saw itself confronted with having the assess the interaction between the rights of the defence and the rights of victims in criminal procedures and how the right balance between both sets of rights can be struck. In this case, suspects Gambino and Hyka were being prosecuted for money laundering and swindling. ${ }^{23}$ Two of their victims were involved in that criminal procedure. The question put to the court pertains to the compatibility of the Italian interpretation and application of the immediacy principle (according to which suspects in Italian proceedings have the right - should the composition of the court change in the course of the proceedings - to demand that all witness/victim interrogations are repeated) ${ }^{24}$ with Directive 2012/2925 (according to which victims have the right - pursuant to Article 16: to have a decision

22 Court of Justice of the European Union (CJEU), 12.12.2019, case C-627/19 (Z.B.).

23 Court of Justice of the European Union (CJEU), 29.07.2019, case C-38/18 (Gambino and Hyka).

24 The importance of this right was also recognised by the ECHR; Pitkänen v. Finland, application $n^{\circ} 30508 / 96,9$ March 2004, $\ 58$ and Beraru v. Romania, application $n^{\circ}$ 40107/04, 18 March 2014, $\$ 64$, which could lead to the need to award accused persons the right to have victims re-interrogated see Cutean v. Romania, application $n^{\circ}$ 53150/12, 2 December 2014, $\$ 61$, and Škaro v. Croatia, application $\mathrm{n}^{\circ}$ 6962/13, 6 December 2016, $\$ 24$. See also $M$. Groenbuijsen and H. Selçuk, The principle of immediacy in Dutch criminal procedure in the perspective of European Human Rights Law, Zeitschrift für die Gesamte Strafrechtswissenschaft, 2014, 126(1), p248-276 or A. Chmiel, Immediacy principle in the Roman criminal procedure, Krytyka Prawa, 2016 (8), p 2-16.

25 Directive 2012/29/EU of the European Parliament and of the Council of 25 October 2012 establishing minimum standards on the rights, support and protection of victims of crime, and replacing Council Framework Decision 2001/220/JHA, OL 2012 L 315.

EuCLR Vol. 10, 2/2020 
regarding their compensation within a reasonable time frame, pursuant to Article 18: to be protected against amongst others secondary victimisation; and pursuant to Article 20: the right to have the number of interrogations kept to a minimum ${ }^{26}$. First, the court explains in its judgment of 29 July 2019, that the victim rights included in Article 20 Directive 2012/29 only pertain to the phase of the criminal investigation, and have no bearing on the trial proceedings themselves. This conclusion is substantiated referring to the preparatory documents and discussions held in the course of drafting the instrument, in which the legislator clearly indicated its will to distinguish between both phases. ${ }^{27}$ In light thereof, in this case, only the compatibility of the Italian legislation ${ }^{28}$ with Articles 16 and 18 Directive 2012/29 is relevant.

Second, the court decided, that even though the repeated interrogation of victims in an individual case could potentially amount to a violation of the safeguards included in Directive 2012/29, the application of the rules included in the Italian domestic law do not necessarily nor automatically have to amount to that. Because the violation of the EU principles is dependent on the concrete application in individual cases, the Directive does not preclude national legislation that allows the suspected or accused persons to demand the witness interrogation to be repeated.

\section{The legal position of people having committed a criminal act in a state of insanity}

In the past year, the CJEU again pointed to the importance of having sufficient regard for the legal position of vulnerable persons subject to a criminal proceeding, in particular persons suffering from a mental disability. ${ }^{29}$ In case C-467/18 E.P., known for suffering from a paranoid schizophrenia, had confessed to murdering his mother. Upon his confession, he was immediately transferred to the emergency unit of a psychiatric hospital. It is striking that E.P. was never interrogated during the criminal investigation, nor was he ever informed of the fact that a criminal procedure was lodged against him. The Public Prosecutor's Office had concluded that compulsory medical measures should be ordered on the ground that E.P. had intentionally committed an offence in a

26 See more in detail on this directive F. Rafaraci, New Perspectives for the Protection of the Victims in the EU, in S. Ruggeri, Human Rights in European Criminal Law, Springer 2014, p 215-225; W. De Bondt, Protecting victims' rights in the European Union: the theory and practice of diversity of treatment during the criminal trial - Belgian National Report, Institute of Advanced Legal Studies, 2013, 1-19.

27 Proposal for a Directive of the European Parliament and of the Council establishing minimum standards on the rights, support and protection of victims of crime, $\mathrm{COM}(2011) 275 \mathrm{fi}-$ nal, Brussels, 18.5.2011.

28 See also G. Alvaro and A. D'Andrea, The Impact of Directive 2012/29/EU on the Italian System for Protecting Victims of Crime in Criminal Proceedings, in S. Ruggeri, Human Rights in European Criminal Law, Springer 2014, p 307-317.

29 See more in detail on the past discussions on this M. Meysman Quo vadis with vulnerable defendants in the EU?, EuCLR 2014 (4), p 179-194 and M. Meysman, The tension between cross-border cooperation in the European area of freedom, security and justice and the fundamental rights of mentally ill offenders in detention, International Journal Of Law And Psychiatry, 2016 (47), 136-147. 
state of mental disorder such that he could not be held to be criminally responsible. That order was served on his daughter. ${ }^{30}$ As no appeal was brought within the prescribed period, that order became final, without E.P. being aware of its existence.

In its judgment of 19 September 2019, the CJEU acknowledged that Directive 2012/13/EU regarding the right to information ${ }^{31}$ and Directive 2013/48/EU regarding access to a lawyer ${ }^{32}$, should be explained as being equally applicable to criminal procedures directed against persons who have committed acts representing a danger to society and who can be admitted to a psychiatric hospital, either on therapeutic and safety grounds.

The CJEU firmly acknowledged that the existing European rules must be interpreted as precluding national legislation, which does not sufficiently enable courts to verify that the procedural rights of persons with a mental disability were respected in proceedings prior to those before that court. Furthermore, the principle of the presumption of innocence referred to in Directive 2016/34333 must be interpreted as requiring even in judicial proceedings for the committal to a psychiatric hospital of persons who have committed acts representing a danger to society in a state of insanity - that the Public Prosecutor's Office provides proof that the person whose committal is sought, is the perpetrator.

\section{The evaluation of detention conditions in foreign prison facilities}

In the course of the next month, the court had to rule on the evaluation of detention conditions in prison facilities of the issuing Member State in the context of interpreting the refusal grounds included in the Framework Decision on the European arrest warrant. In case C-128/18 Dorobantu, a Romanian citizen, was suspected of having committed several counts of offences relating to property and to forgery (including the use of forged documents). ${ }^{34}$ A European arrest warrant for the arrest of Dorobantu with a view to his prosecution was issued in Romania. He is subsequently arrested in Germany where his surrender to the Romanian authorities is considered to be lawful.

30 Whereas the English translation of the judgement states that the order was served on his sister, the Bulgarian version states that the order was served on his daughter. Given that the request for a preliminary ruling was brought to the District Court in Lukovit, Bulgaria, the Bulgarian language version was treated with precedence.

31 Directive 2012/13/EU of the European Parliament and of the Council of 22 May 2012 on the right to information in criminal proceedings, OL $2012 \mathrm{~L} 142$.

32 Directive 2013/48/EU of the European Parliament and of the Council of 22 October 2013 on the right of access to a lawyer in criminal proceedings and in European arrest warrant proceedings, and on the right to have a third party informed upon deprivation of liberty and to communicate with third persons and with consular authorities while deprived of liberty, OJ 2013 L 294.

33 Directive (EU) 2016/343 of the European Parliament and of the Council of 9 March 2016 on the strengthening of certain aspects of the presumption of innocence and of the right to be present at the trial in criminal proceedings, OJ $2016 \mathrm{~L} 65$.

34 Court of Justice of the European Union (CJEU), 15.10.2019, case C-128/18 (Dorobantu).

EuCLR Vol. 10, 2/2020 
Dorobantu appeals this order and the case is brought to the CJEU with a view to receiving a clarification regarding the minimum standards detention facilities have to meet in light of Article 4 of the EU Charter of Fundamental Rights; what standards are to be used to assess whether detention conditions comply with the fundamental rights guaranteed by EU law, as well as the interpretation of the term 'real risk' within the meaning of the judgment Aranyosi and Căldăraru ${ }^{35}$.

In its judgment of 15 October 2019, the CJEU repeats that, in principle, executing judicial authorities may only refuse to execute a warrant on the grounds for non-execution exhaustively listed by Framework Decision 2002/584 and that the execution of the warrant may be made subject only to one of the conditions exhaustively laid down in Article 5. While execution of the European arrest warrant constitutes the rule, refusal to execute is intended to be an exception which must be interpreted strictly. Nonetheless, the CJEU also recognised that other limitations may be placed on the principles of mutual recognition and mutual trust between Member States in exceptional circumstances'. In that context, the Court stated that, subject to certain conditions, the executing judicial authority has an obligation to bring the surrender procedure to an end where surrender may result in the requested person being subjected to inhuman or degrading treatment within the meaning of Article 4 of the Charter.

Following up on this obligation means that when the executing judicial authority has objective, reliable, specific and properly updated information showing there to be systemic or generalised deficiencies in the conditions of detention in the prisons of the issuing Member State, it may have to refuse cooperation. In making this assessment, it must take account of all the relevant physical aspects of the conditions of detention in the prison in which it is actually intended that that person will be detained. Reference is made to the personal space available to each detainee in that prison, ${ }^{36}$ to sanitary conditions and to the extent of the detainee's freedom of movement within the prison. Importantly, the CJEU stresses that this assessment is not limited to the review of obvious inadequacies. The executing judicial authority must request all information that it deems necessary and where there are no specific indications that the detention conditions would violate European standards, it must rely on the assurances given by the issuing judicial authority.

35 Court of Justice of the European Union (CJEU), 05.04.2016, joint cases C-404/15 and C-659/15 PPU (Aranyosi and Căldăraru). G. Anagnostaras, Mutual confidence is not blind trust! Fundamental rights protection and the execution of the European arrest warrant: Aranyosi and Caldararu, Common Market Law Review 2016 (6), p. 1675-1704. K. Bovend'eerdt, The Joined Cases Aranyosi and Caldararu: A New Limit to the Mutual Trust Presumption in the Area of Freedom, Security, and Justice, Utrecht Journal of International and European Law, 2016, 32(83), 112-121; M. Rogan, What constitutes evidence of poor prison conditions after Aranyosi and Căldăraru? Examining the role of inspection and monitoring bodies in European Arrest Warrant decision-making, New Journal of European Criminal Law, 2019, 3(10), 209-226.

36 As regards the personal space the court takes note of the absence of explicit binding EU minimum standards. In absence thereof, it refers to Article 3 ECHR. 
The fact that legal remedies exist in the issuing Member State, allowing a detainee to challenge his detention conditions, does not relieve the executing judicial authority from its evaluation responsibilities and should not be used as an argument ruling out the existence of a real risk of inhuman or degrading treatment. ${ }^{37}$

\section{Right to an effective remedy}

Also, in October 2019, the CJEU looked into the extent to which European Union law requires suspects to effectively have access to legal remedies in certain situations. In case C-324/17, the initiative was taken to issue a European investigation order ${ }^{38}$ in the context of a criminal investigation against Gavanozov, suspected of heading a criminal organisation and having committed several fiscal criminal offences. ${ }^{39}$ The Bulgarian referring judge - at the occasion of filling out the form annexed to the Directive on the European investigation order - questioned the extent to which the instrument requires that a right to legal remedy is enshrined in the national legal framework. This question was sparked by box ' $J$ ', requiring the issuing state to detail the legal remedies used by the person involved. ${ }^{40}$

In its judgment of 24 October 2019, the CJEU reiterates the objectives of the directive, being facilitating and accelerating judicial cooperation between Member States on the basis of the principles of mutual trust and mutual recognition. In light thereof, the boxes included in the form are intended to provide the executing authority with the minimum official information required to enable it to adopt the decision on the recognition or execution of the EIO in question and, as appropriate, to carry out the measure requested within the time limits laid down in Article 12 of that Directive. The form does not require the issuing state to provide a full-fledged description of the legal remedies, if any, that are available in the issuing Member State. Only the remedies used should be referred to. Therefore, the question whether the person involved should at all have a right to a remedy, is not relevant for the interpretation of the information that the issuing Member State is to provide in the form. ${ }^{41}$ The form cannot be interpreted as granting individuals the right to a legal remedy.

37 See also J. Banach-Gutierrez, The surrender of prosecuted persons under the EAW procedure: Issues of transposition of EU criminal policy to the national level, New Journal of European Criminal Law, 2020, p. 1-15.

38 Directive 2014/41/EU of the European Parliament and of the Council of 3 April 2014 regarding the European Investigation Order in criminal matters, OJ 2014 L 130.

39 Court of Justice of the European Union (CJEU), 24.10.2019, case C-324/17 (Gavanozov).

40 Box J reads: 'Please indicate if any legal remedy has been sought against the issuing of an $\mathrm{EIO}$, and if so, please provide further details'.

41 This case is also included in the analysis in V. Mitsilegas, Autonomous concepts, diversity management and mutual trust in Europe's area of criminal justice, Common Market Law Review, 2020, 57(1), 45-78.

EuCLR Vol. 10, 2/2020 


\section{Presumption of innocence}

D.K. is placed in pre-trial detention, accused of being a member of a criminal organisation and of being involved in a murder case. According to the applicable Bulgarian national law, the pre-trial detention of a persons is not assessed ex officio. To the contrary, if a court rules that the detention is lawful, the detention continues for an indefinite period and is not subsequently re-examined of the court's own motion. The release of the person held in detention cannot be granted unless that person makes an application to that end and proves the existence of new circumstances justifying his release. The release of a person held in pre-trial detention therefore depends on that person being able to establish the existence of new circumstances justifying a release. This national law was subject to scrutiny in case C-653/19 PPU. ${ }^{42}$ The referring judge invited the CJEU to rule on the compatibility of this national law with Article 6 and recital 22 of Directive 2016/343 ${ }^{43}$ and with Articles 6 and 47 of the EU Charter of Fundamental Rights, which refer to the principle that the burden of proof for establishing the guilt of suspects and accused persons is on the prosecution and that the presumption of innocence would be infringed if the burden of proof is shifted from the prosecution to the defence.

The CJEU explains that Article 6 Directive 2016/343 is not applicable to this case, because these release decisions do not pertain to either or not being guilty. The rules and practices regarding the burden of proof are solely governed by national criminal law. Furthermore, the person involved cannot seek recourse to the principles in the EU Charter of Fundamental Rights as those principles are only applicable to Member States in their execution of EU law. Given that the burden of proof is governed by national law, the Charter principles do not apply. ${ }^{44}$

The presumption of innocence also played a central role in case C-671/18, which related to Z.P. being convicted to paying a financial penalty of 232 euro after being convicted for a road traffic offence. ${ }^{45}$ This is the final case in this overview. Fully in line with Dutch national law, the requirement to pay the financial penalty was notified by placing it in Z.P.'s letter box. It was detailed in the official documents which deadline applied for exercising the right to contest the case. In absence of any such contestation, the penalty had become final.

42 Court of Justice of the European Union (CJEU), 28.11.2019, case C-653/19 (D.K.).

43 Directive (EU) 2016/343 of the European Parliament and of the Council of 9 March 2016 on the strengthening of certain aspects of the presumption of innocence and of the right to be present at the trial in criminal proceedings, OJ $2016 \mathrm{~L} 65$.

44 For reasons of completeness, it should be added that in recent academic debate this position of the court is questioned. Mirroring the fact that obligations regarding procedural safeguards de facto have a scope beyond mere cooperation in criminal matters, some authors argue that this impacts on the scope of the Charter. See e.g. J. Owwerkerk, EU Competence in the Area of Procedural Criminal Law: Functional vs. Self-standing Approximation of Procedural Rights and Their Progressive Effect on the Charter's Scope of Application, European Journal of Crime, Criminal Law and Criminal Justice 2019 (2), 89-96.

Court of Justice of the European Union (CJEU), 05.12.2019, case C-671/18 (Z.P.). 
When confronted with the execution of the penalty, Z.P. submitted that, on the date of the contested offence, he had already sold the vehicle in question and had informed his insurer thereof. He admitted that he had not informed the authority responsible for the registration of the vehicle. Furthermore, Z.P. maintained before the referring court that the official documents placed in his letter box were incomprehensible to him and that he was not aware of the official nature thereof.

In its judgment of 5 December 2019, the CJEU substantiates why there is no valid ground for Poland to refuse cooperation and execution of the Dutch decision. The CJEU contends that Article 7 Framework Decision 2005/21446 must be interpreted as meaning that, where a decision requiring payment of a financial penalty has been notified in accordance with the national legislation of the issuing Member State (in this case indicating the right to contest the case and the time limit for such a legal remedy), the authority of the executing Member State may not refuse to recognise and execute that decision provided that the person concerned has had sufficient time to contest that decision, which is for the national court to verify. Additionally, the fact that the procedure imposing the financial penalty in question is administrative in nature is not relevant in that regard. Furthermore, Article 20 (3) Framework Decision 2005/214 must be interpreted as meaning that the competent authority of the executing Member State may not refuse to recognise and execute a decision requiring payment of a financial penalty in respect of road traffic offences where such a penalty has been imposed on the person in whose name the vehicle in question is registered on the basis of a presumption of liability laid down in the national legislation of the issuing Member State, provided that that presumption may be rebutted.

\section{Conclusion}

In the course of 2019, the Luxembourg court was invited to reflect and rule on the interpretation of different provisions within the EU's legal framework governing cooperation in criminal matters. Analysis of the court's case law revealed that eight themes can be distinguished across eight cooperation instruments. (1) Since the execution of a confiscation order is governed by the law of the executing Member State, that Member State can seek recourse to imprisonment in case of non-execution without prior notification let alone consent of or legislative reciprocity in the issuing Member State. (2) Requests for preliminary rulings on the interpretation of EU cooperation instruments have no bearing on the deadlines set for release of persons arrested in execution of a European arrest warrant. (3) Questions relating to the interpretation of the concept 'competent judicial authority' within the meaning of instruments governing cooperation in criminal matters, gave way to a series of judgements, clarifying the position of public prosecutors in issuing a European arrest warrant. (4) The Directive on Victim

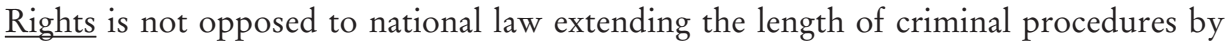

46 Council Framework Decision 2005/214/JHA of 24 February 2005 on the application of the principle of mutual recognition to financial penalties, OJ $2005 \mathrm{~L} 76$.

EuCLR Vol. 10, 2/2020 
requiring interrogations to be repeated for this would not surely and automatically infringe the rights protected therein. (5) The choice to admit a person to a psychiatric hospital for having committed acts representing a danger to society in a state of insanity, has no bearing on the applicability of the Directive on the right to information and the Directive on the access to a lawyer. (6) Despite the fact that the mutual recognition principle requires a strict interpretation of the refusal grounds included in the cooperation instruments, the executing judicial authority always remains obliged to refuse cooperation where such may result in the person being subjected to inhuman or degrading treatment within the meaning of Article 4 of the EU Charter of Fundamental Rights. (7) The formulation of the certificate annexed to the European investigation order must not be interpreted as requiring Member States to introduce a right to an effective legal remedy to the issuing thereof. (8) The Directive on the presumption of innocence only applies to procedures that result in decision rendering a person either or not guilty. As a starting point, the EU Charter of Fundamental Rights only applies to Member States in execution of European legal instruments. Differences in rules criminalising road traffic offences and/or the notification of financial penalties do not constitute a valid legal basis to refuse cooperation, if all procedural safeguards relating to a.o. the presumption of innocence have been met. 